\title{
Synapse alterations in autism: Review of animal model findings
}

\author{
Martina Zatkovaa , Jan Bakos ${ }^{\mathrm{a}, \mathrm{b}}$, Julius Hodosy ${ }^{\mathrm{a}, \mathrm{c}, \mathrm{d}}$, Daniela Ostatnikova ${ }^{\mathrm{a}}$
}

\begin{abstract}
Background. Recent research has produced an explosion of experimental data on the complex neurobiological mechanisms of developmental disorders including autism. Animal models are one approach to studying the phenotypic features and molecular basis of autism. In this review, we describe progress in understanding synaptogenesis and alterations to this process with special emphasis on the cell adhesion molecules and scaffolding proteins implicated in autism. Genetic mouse model experiments are discussed in relation to alterations to selected synaptic proteins and consequent behavioral deficits measured in animal experiments.
\end{abstract}

Methods. Pubmed databases were used to search for original and review articles on animal and human clinical studies on autism.

Results. The cell adhesion molecules, neurexin, neurolignin and the Shank family of proteins are important molecular targets associated with autism.

Conclusion. The heterogeneity of the autism spectrum of disorders limits interpretation of information acquired from any single animal model or animal test. We showed synapse-specific/ model-specific defects associated with a given genotype in these models. Characterization of mouse models with genetic variations may help study the mechanisms of autism in humans. However, it will be necessary to apply new analytic paradigms in using genetically modified mice for understanding autism etiology in humans. Further studies are needed to create animal models with mutations that match the molecular and neural bases of autism.

Key words: autism, synaptogenesis, cell adhesion molecules, scaffolding proteins, animal models

Received: May 21, 2015; Accepted with revision: December 4, 2015; Available online: January 5, 2016

http://dx.doi.org/10.5507/bp.2015.066

a Institute of Physiology, Comenius University, Bratislava, Slovak Republic

${ }^{b}$ Institute of Experimental Endocrinology, Bratislava, Slovak Republic

' Institute of Molecular Biomedicine, Comenius University, Bratislava, Slovak Republic

${ }^{d}$ Center for Molecular Medicine, Slovak Academy of Sciences, Bratislava, Slovak Republic

Corresponding author: Jan Bakos, e-mail:j.bakos@savba.sk

\section{INTRODUCTION}

Autism spectrum disorder (ASD) is a neurodevelopmental disorder with heterogeneous phenotype predominantly affecting males ${ }^{1}$. According to the World Health Organization (WHO), there is a global median prevalence of autism spectrum disorder estimated at $62 / 10000$, that is one child in 160 . The median rate of prevalence for Europe is 61.9/10 000 and for America is 65.5/10 000 (ref. ${ }^{2}$ ). Although still a matter of debate, the most common symptoms of autism include social and communication impairments and repetitive behavior. Currently, no single cause of ASD is known and pharmacological treatments for the core symptoms are not available ${ }^{1}$.

Numerous animal models (lesion, transgenic, knockout, selective breeding, etc.) have been developed for a variety of psychiatric, neurodegenerative, and neurodevelopmental disorders. Animal models are often used to study maternal immune activation, genetic defects and environmental factors in autism too ${ }^{3-5}$. Mouse models for genetic defects include nonsyndromic autism associated mutations in single genes. The most common mutations in this context include cell adhesion molecules: neuroligins, neurexins and scaffolding proteins, i.e. Shank proteins. Neuroligins, neurexins and Shank proteins are synaptic proteins important for the formation of neural circuits and brain development. The other group of models represents syndromic autism associated mutations in a single gene, for example fragile $\mathrm{X}$ syndrome and Rett syndrome. Genetic mouse models of fragile $\mathrm{X}$ syndrome and Rett syndrome are experimentally used to examine the effects of environmental stimulation on behavioral deficits ${ }^{6}$.

In autistic subjects, abnormalities of brain growth and connectivity are usually apparent after the first year of life ${ }^{7,8}$. Early developmental stages are characterized by generation of new neurons, dendritic growth, synaptogenesis, neural circuit formation and experience-dependent remodeling ${ }^{9}$. Recent studies have suggested that early-life deprivation during a sensitive period can lead to commitments that are difficult to reverse at later ages ${ }^{10}$. The early years of development are crucial for the formation of neural circuits when there is a high predisposition to disruption. Thus, research on autism may benefit from transgenic mouse models and/or aversive stimuli at different stages of development. This review describes the most important mechanisms in synapse formation and synapse alterations in autism spectrum disorders, followed by a review of the results of experimental tests on animal models with mutations in neurexins, neuroligins and Shank genes. 


\section{Synapse formation}

The formation of the nervous system requires multiple developmental events such as neuronal cell fate specification, cell migration, dendritic growth, axon guidance, synaptic target selection and synaptogenesis ${ }^{11-13}$. All of these developmental steps have to be completed for both interconnections of microcircuits in the brain and peripheral innervations of a specific tissue. By mediating the information flow between neurons, synaptogenesis is the final step in the development of the nervous system that provides regulation of intercellular communications within the nervous system. After the completion of the process of axon guidance and target recognition, synapse formation proceeds. One of the first steps in synaptogenesis is the induction and adhesion of opposed presynaptic and postsynaptic domains. This is mediated by cell adhesion molecules which trigger the events that lead to the assembly and differentiation of pre- and postsynaptic specializations $^{13}$. These molecules can have several different functions. They promote stability of neuronal connections by linking synaptic partners. Furthermore, the cell adhesion molecules regulate differentiation of pre- and postsynaptic specialization and they participate in modulation of synaptic structure and function ${ }^{14}$.

The second step in synaptogenesis is organization of pre synaptic and postsynaptic specializations by scaffolding proteins. These proteins are critical mediators in assembling synaptic proteins into domains specialized for neurotransmitter release and reception. Scaffolds form a link between the adhesion proteins, ion channels, neurotransmitter receptors, intracellular signaling cascades, and the actin cytoskeleton ${ }^{15}$

Synaptogenesis includes regulation of growth by intercellular signaling pathways. Synaptic growth is regulated by anterograde and retrograde signaling molecules, including the wingless family proteins (Wnt) and the bone morphogenetic protein pathway. The Wnt signaling molecules are important for a broad range of processes, from neurogenesis to synaptic plasticity ${ }^{16}$. At the presynaptic site, Wnt regulates cytoskeleton dynamics through inhibition of glycogen synthase kinase- $3 \beta$ (ref. ${ }^{17-18}$ ). This cytoplasmic pathway component interacts with actin and the microtubules. Postsynaptically, Wnt signaling promotes the growth of the postsynaptic membrane by translocation of the cleaved receptor Frizzled into the nucleus ${ }^{19}$. The retrograde bone morphogenetic protein pathway includes transcription factors which target multiple genes, including Rac GTPase activator ${ }^{20}$. This type of GTPase regulates the actin cytoskeleton and it is important for the growth of dendritic spines ${ }^{21}$. Impairment in the bone morphogenic protein has been found in fragile $\mathrm{X}$ syndrome ${ }^{22}$. When growth signals are released, such as Wnts and bone morphogenetic proteins, they bind to the synaptic transmembrane receptors and are internalized as receptor-ligand signaling complexes. These complexes are transported within the endosomal system, which in synaptic development is critical for activity-dependent circuit refinement ${ }^{15}$.

\section{Role of the cell adhesion molecules in synapse formation}

Many cell adhesion molecules are localized at synaptic sites in neuronal axons and dendrites. These include

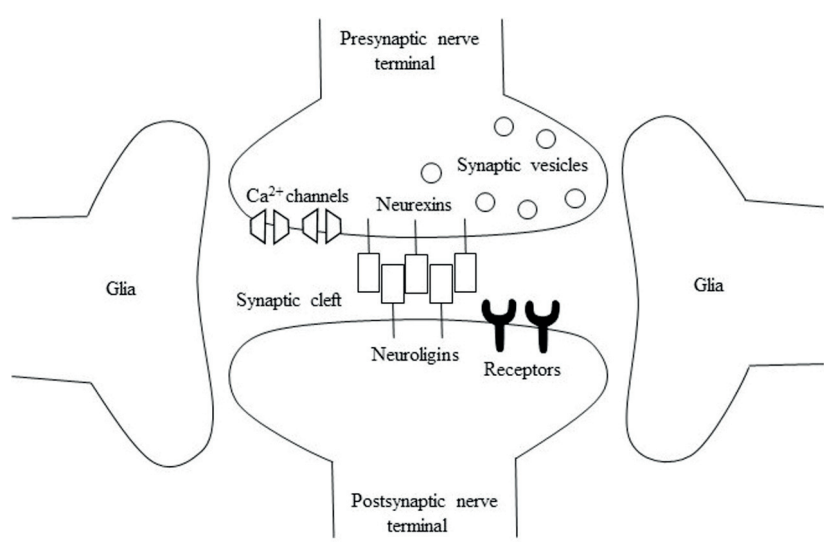

Fig. 1. Interaction of neurexins and neuroligins in transsynaptic complex. Neurexins are located on the presynaptic terminal and neuroligins on the postsynaptic nerve terminal.

neurexins and neuroligins. These molecules form the trans-synaptic adhesion complex molecules that connect presynaptic and postsynaptic neurons at synapses and mediate trans-synaptic signaling ${ }^{23}$. Neurexins and neuroligins interact with each other in a $\mathrm{Ca}^{2+}$ dependent manner (Fig. 1).

Neurexins act predominantly on the presynaptic terminal in neuronal cells and play essential roles in the neurotransmission and differentiation of synapses ${ }^{24}$. Each of three human neurexin genes (neurexin 1-3) generates transcripts under the control of two separate promoters for two neurexin isoforms, the longer neurexin- $\alpha$ form and the shorter neurexin- $\beta$ form (ref. ${ }^{25}$ ). Another important member of the neurexin family of proteins includes contactin-associated protein-like 2 (CNTNAP2), which is involved in neuron-glia interactions and clustering $\mathrm{K}^{+}$ channels in myelinated axons ${ }^{26}$.

Neuroligins are synaptic cell adhesion molecules that are enriched in postsynaptic membranes where they may recruit receptors, channels, and signal-transduction molecules $^{27}$. Neuroligins are encoded by four human genes (neuroligin 1-4), and like neurexins, undergo alternative splicing ${ }^{25}$. Interestingly, mammals express only three or four genes ${ }^{28}$.

In the rodent brain, all three neuroligin (neuroligin 1-3) proteins are detected at low levels before birth and increase rapidly during the first three postnatal days. The plateau of these proteins culminates during the period when most synapses are formed and they remain at high levels during adulthood ${ }^{29}$. The expression of neuroligin 1 and neuroligin 2 in the CNS is restricted to the excitatory and inhibitory synapses. Although neuroligin 3 is expressed mainly by neurons, a few studies suggest that neuroligin 3 can be expressed by the glial cells, astrocytes and Schwann cells in the developing embryo ${ }^{30}$.

\section{Role of the scaffolding proteins in synapse formation}

As mentioned above, the interactions between the cell adhesion molecules and the scaffolding proteins are essential for functional synapse formation. Scaffolding proteins include a large group of mutually binding syn- 
aptic proteins. In the developing brain, space and time regulation of expression of scaffolding proteins determine the morphology of neuronal processes and consequently synaptogenesis. A number of structurally related forms of scaffolding proteins have been identified. The most important group is the ankyrin related proteins. These proteins contain multiple domains for protein-protein interaction, including ankyrin repeats, and the SH3 domain. Particular members of this family are Shank proteins. Shank1-3 are synaptic scaffolding proteins that interact with a variety of membrane and cytoplasmic proteins. These proteins bind to neurexin-neuroligin complexes at postsynaptic excitatory glutamatergic synapses ${ }^{26}$. Specific positioning of Shank proteins at the postsynaptic sites of excitatory synapses suggests a role for this protein family in the organization of cytoskeletal/signaling complexes at specialized cell junctions ${ }^{31}$. Moreover, the neurexin-neuroligin-Shank pathway is required during the stabilization phase of the synapse in response to neuronal activity ${ }^{32}$.

Formation of trans-synaptic neurexin-neuroligin complex is essential for neural circuit function resulting in transforming an assembly of synapses into fully functional units. Moreover, neuroligins and neurexins are involved in maintaining the excitatory/inhibitory balance within the nervous system. Mutations in the genes of cell-adhesion and scaffolding molecules might be important in the development of autism spectrum disorders.

\section{Synaptic alterations in autism}

Autism spectrum disorder is a pervasive neurodevelopmental disorder characterized by marked disruption in information processing and cognition. Many studies have found altered synaptic plasticity in the brains of affected individuals ${ }^{33-35}$. The early onset of ASD and relatively small pathological changes in the brain of patients with ASD led to the hypothesis that impaired synapse formation, neuronal connectivity and circuit stabilization may explain the pathogenesis of this disease $\mathrm{e}^{7,36,37}$.

Altered neuronal activity in ASD might be a reflection of disturbed synaptic integrity due to altered expression of cell adhesion and scaffolding molecules involved in synaptic development. Many of these molecules are associated with ASD, including neuroligins, neurexins, and Shank $3^{26}$. In particular, alterations in the genes encoding neuroligins 3 and 4, their binding partners neurexins 1 and 3, Shanks and CNTNAP2 are implicated in synaptic changes in autism ${ }^{38}$. Many other genes encoding synaptic proteins involved in cell adhesion and scaffolding are associated with autism as can be seen from Table 1 .

\section{Alterations in genes encoding cell adhesion molecules and scaffolding proteins implicated in autism}

Patients with mutations in the genes encoding neuroligins suffer from disruption in excitatory/inhibitory balance in terms of increasing the excitatory/inhibitory ratio, which in turn may disrupt the sensory, social and emotional systems ${ }^{40}$. One type of neuroligin mutation that led to autism in a pair of Swedish twins was found to be R451 substitution in neuroligin 3. This mutation led to a $90 \%$ loss of total neuroligin 3 levels and also to a pre-
Table 1. List of major genes involved in cell adhesion and scaffolding associated with autism ${ }^{39}$.

\begin{tabular}{ll}
\hline Gene & Gene product \\
\hline NL3, NL4 & Neuroligin 3, neuroligin 4 \\
NRXN1 & Neurexin 1, neurexin 3 \\
SHANK3 & SH3 and multiple ankyrin repeat domains 3 \\
CNTN3 & Contactin 3 \\
CNTNAP2 & Contactin-associated protein 2 \\
CDH9, & Cadherin 9, cadherin 10 \\
CDH10 & \\
L1CAM & L1 cell adhesion molecule \\
NRCAM & Neuronal cell adhesion molecule \\
PCDH10 & Protocadherin 10 \\
\hline
\end{tabular}

dominant endoplasmic reticulum retention of neuroligin 3 $\left(\right.$ ref. $\left.^{41,42}\right)$. In a large French family, a two-base pair deletion (1253delAG) was found that resulted in a premature stop codon in the sequence of the normal neuroligin 4 gene. Two members of the family suffered from autism, other members had non-specific X-linked mental retardation or pervasive developmental disorder ${ }^{43}$. Rare copy number variations and/or point mutations in the neurexin gene have been reported in the context of autism pathology. Deletion of the neurexin $1 \alpha$ promoter and exons 1-5 in a boy with autistic characteristics has been described in one study ${ }^{44}$. In another study, a deletion that eliminated several neurexin 1 exons, including $1 \alpha$ and $1 \beta$, in two female siblings was found in one ASD family ${ }^{45}$. Deletions of neurexin 3 were found in four ASD individuals. One was a de novo mutation, another one was inherited from a nonaffected parents and the third was inherited from a father with subclinical autism ${ }^{46}$. Rare non-synonymous variants of mutation of CNTNAP2, a member of the neurexin family ${ }^{47}$, have been found in ASD patients. Several other studies have also found other polymorphisms of CNTNAP2 associated with ASD (ref. ${ }^{48-50}$ ).

Shank3 was the first gene from the Shank family reported to be associated with ASD. The Shank3 gene is located on chromosome 22q13.3. Three families with ASD were observed to carry alterations of $22 q$ and/or the Shank3 gene $^{51}$. In the first family, an individual carried a de novo deletion of $22 \mathrm{q} 13$. In the second family, two affected siblings carried also a de novo deletion, but they were heterozygous for an insertion of a guanine nucleotide in exon 21. In the last family, a terminal $22 \mathrm{q}$ deletion was identified in a girl affected autism who exhibited language delay. De novo deleterious mutations of Shank2 in ASD have also been identified ${ }^{52-54}$. Shank 1 gene rare mutation has also been associated with ASD (ref. ${ }^{55}$ ).

\section{Genetic mouse models with respect to alterations in cell adhesion molecules and scaffolding proteins}

Neurobiological studies using animal models are important for defining the core characteristics of ASD. Mutations in neurexins, neuroligins and Shank genes might have impact on the development of complex behaviors. Neuroligin 1 mutant mice targeting the first two 
coding exons displayed a mild ASD-related phenotype ${ }^{56}$. They showed increased repetitive, stereotyped grooming behavior. The mice displayed impaired spatial learning and memory in a Morris water maze test. Interestingly, Neuroligin 1 mutant mice displayed few deficits in social behavior. In only one of several tasks, Neuroligin 1 knockout (KO) mice interacted less with a caged adult target. In other social tasks, these mice showed normal interaction and approach to social targets and normal social recognition. They also showed normal anxiety-like behavior, locomotor activity, motor coordination/learning, auditory startle responses, and sensitivity to sensory stimuli. Neuroligin 1 KO mice showed altered sensitivity to pain and heat stimuli but no change in the perception of auditory stimuli ${ }^{57}$.

Neuroligin 2 mutant mice targeting the first coding exon displayed abnormal communication with decreased number of pup ultrasonic vocalizations. These mice displayed marked increase in anxiety-like behavior, a decrease in pain sensitivity, exploration and a slight decrease in motor coordination. The mutant mice displayed delays in several developmental milestones (growth parameters, eye opening, teeth eruption and the acquisition of several reflexes). In contrast, social interactions, and social behavior appeared normal. Acoustic, tactile, olfactory sensory information processing and sensorimotor gating (the state-dependent regulation of transmission of sensory information to the motor system) were not affected ${ }^{58,59}$.

Neuroligin 3 mutant mice, targeting exons 2-3 displayed behavioral phenotype reminiscent of the lead symptoms of ASD (ref. ${ }^{56}$ ). These mice displayed reduced ultrasonic vocalization and a lack of social novelty preference. These observations might be related to the olfactory deficiency observed in the Neuroligin 3 mutants. The mice displayed enhanced motor activity in the open field, however anxiety-like behavior evaluated in the elevated plus maze test appeared normal. They also showed normal motor performance on the rotarod, and no gross performance deficits in a Morris water maze test. These mice displayed normal duration of time spent in social interaction, prepulse inhibition of the startle response (to access sensorimotor gating) and sucrose preference ${ }^{60}$.

Neuroligin 3 R451C knockin (KI) mice were also generated for illustrating the association of neuroligin 3 and ASD (ref. ${ }^{61}$ ). This mutation substitutes cysteine for arginine at residue 451 in Neuroligin 3, a gene located on the X-chromosome. This results in neuroligin 3 retention in the endoplasmic reticulum and a decreased delivery of the protein to the cell surface ${ }^{62,63}$. Neuroligin $3 \mathrm{KI}$ mice show impaired sociability and enhanced spatial learning and memory in a Morris water maze test ${ }^{42,64}$. In the study of Chadman et al. ${ }^{62}$, juvenile reciprocal social interaction, adult social approach and cognitive abilities were normal in these mice butit was also found that these mice showed from minor developmental differences including slightly different rates of somatic growth, slower righting reflexes, faster homing reflexes in females and more vocalizations. Longer latencies to fall from the rotarod and less vertical activity in the open field in Neuroligin $3 \mathrm{KI}$ mice were observed $^{62}$.
Neuroligin 4 mutant mice also display ASD-related behaviors. Deficits in social interactions and ultrasonic communications were observed in these mice ${ }^{65}$. Further, aggression, nest-building parameters, as well as selfgrooming and circling as indicators of repetitive stereotypes were explored in these mutant mice ${ }^{66}$. However, in another study, the authors failed to confirm the social or communication deficits. In the same study, anxiety-like behaviors, self-grooming, motor coordination and open field exploration did not differ across the genotypes. Measures of developmental milestones also remained unchanged ${ }^{67}$.

Neurexin $1 \alpha$ mutant mice represent mice lacking neurexin $1 \alpha$-encoded isoforms targeting the first coding exon yields. These mice display a mild ASD-related phenotype. The authors of the study Etherton et al. ${ }^{68} \mathrm{ob}-$ served a decrease in prepulse inhibition, an increase in grooming behaviors, impaired nest-building activity, and enhanced motor learning in these mice ${ }^{68}$. In the same study, neurexin $1 \alpha$ deficient mice did not exhibit any obvious changes in social behaviors, anxiety-like behaviors, locomotor activity or spatial learning. However, the authors Grayton et al. ${ }^{69}$ observed an altered social approach, reduced social investigation and reduced locomotor activity in a novel environment ${ }^{69}$. Males displayed increased aggressive behavior as well.

Neurexin $2 \mathrm{KO}$ mice are generated by targeting exon 23 , which is shared by $\operatorname{Nrxn} 2 \alpha$ and $\operatorname{Nrxn} 2 \beta$ (ref. ${ }^{70}$ ). These mice display behavioral abnormalities, characterized by deficits in social interaction and anxiety-like behavior ${ }^{71}$. Dachtler et al. ${ }^{72}$ reported also deficits in social memory, but prepulse inhibition and passive avoidance learning were normal.

Genetic mouse models of different Shank protein mutations were produced to investigate their contribution to autistic pathology. Shank1 mutant mice with a deletion of exons 14 and 15 resulted in the knockout of all detectable Shank1 proteins in these animals ${ }^{22}$. Shank1 mutant mice showed decreased movement in the open field test, anxiety-like behavior measured by a light/dark test and open field test. They showed a deficit in motor learning measured by rotarod, also a deficit in contextual fear conditioning and communicative behaviors by ultrasonic vocalizations. Interestingly, spatial learning and memory were enhanced ${ }^{73-75}$.

Two different lines of Shank2 mutant mice were generated. Won et al. ${ }^{76}$ described exons 6-7 deletion mice and Schmeisser et al. ${ }^{77}$ reported on exon 7 deletion mutant mice. Mutant mice with exons 6-7 deletion exhibited ASD-like behaviors including reduced social interaction, reduced social communication by ultrasonic vocalizations, and repetitive jumping. These mice displayed impaired spatial learning and memory in a Morris water maze test, but novel object recognition memory was normal. Impaired nesting behavior, hyperactivity in the open field test and anxiety-like behavior in an elevated plus maze were also reported ${ }^{76}$. Animals with mutation targeting exon 7 also showed profound autistic-like behavioral alterations including repetitive grooming and abnormalities in vocal and social behaviors. Moreover, these mice showed anxiety-like behavior in the light/dark test, hyper- 
activity in the open field test, but normal learning and memory in novel object recognition test ${ }^{77}$.

Different lines of Shank 3 mutant mice carrying different mutations in Shank3 gene have been reported. Mutant mice with exons 4-9 deletion (JAX 017890) displayed a mild ASD-related phenotype. These mice showed normal sociability and social novelty, impairment in juvenile or male-female pair interactions, normal pup ultrasonic vocalizations with decreased adult ultrasonic vocalizations, an increase in self-grooming and inflexibility in the Morris water maze test. These mice showed slight hypoactivity in the open field test, but no enhanced anxiety-like behavior

Table 2. Behavioral changes resulting from alterations in cell adhesion molecules and scaffolding proteins in mouse autism model.

\begin{tabular}{|c|c|c|c|c|}
\hline Alteration & Model & Behavioral test & Result & Ref. \\
\hline$\downarrow$ NL1 & NL1 (-/-) & $\begin{array}{l}\text { Social interaction } \\
\text { Repetitive grooming } \\
\text { Morris water maze } \\
\text { Test of footshock } \\
\text { Test of hotplate sensitivity }\end{array}$ & $\begin{array}{l}\downarrow \text { social interaction } \\
\uparrow \text { stereotyped behavior } \\
\downarrow \text { spatial learning and memory } \\
\downarrow \text { sensitive to footshock } \\
\uparrow \text { sensitive to heat }\end{array}$ & 57 \\
\hline$\downarrow$ NL2 & NL2 (-/-) & $\begin{array}{l}\text { Open field } \\
\text { Elevated plus maze test } \\
\text { Light/dark test } \\
\text { Social approach task } \\
\text { Ultrasonic vocalization } \\
\text { Rotarod } \\
\text { Test of footshock } \\
\text { Test of hotplate sensitivity }\end{array}$ & $\begin{array}{l}\downarrow \text { motor activity } \\
\downarrow \text { vertical activity } \\
\uparrow \text { anxiety } \\
\downarrow \text { motor activity } \\
\uparrow \text { anxiety } \\
\downarrow \text { motor activity } \\
\downarrow \text { vocalization } \\
\downarrow \text { motor coordination } \\
\downarrow \text { rotarod learning } \\
\downarrow \text { pain sensitivity } \\
\downarrow \text { pain sensitivity } \\
\end{array}$ & 58,59 \\
\hline$\downarrow$ NL3 & NL3 (-/-) & $\begin{array}{l}\text { Open field } \\
\text { Elevated plus maze test } \\
\text { Social novelty preference } \\
\text { Buried food-finding test } \\
\text { Ultrasonic vocalization } \\
\text { Hole board test } \\
\text { Fear conditioning test }\end{array}$ & $\begin{array}{l}\uparrow \text { motor activity } \\
\uparrow \text { motor activity } \\
\downarrow \text { social novelty preference } \\
\downarrow \text { olfaction } \\
\downarrow \text { vocalization } \\
\uparrow \text { explored holes } \\
\downarrow \text { freezing response }\end{array}$ & 60 \\
\hline$\uparrow \mathrm{NL3}$ & $\begin{array}{l}\text { NL3 R451C } \\
\text { knockin }\end{array}$ & $\begin{array}{l}\text { Open field } \\
\text { Elevated plus maze test } \\
\text { Social interaction } \\
\text { 3-chamber sociability } \\
\text { Ultrasonic vocalization } \\
\text { Rotarod } \\
\text { Morris water maze } \\
\text { Acoustic startle threshold }\end{array}$ & $\begin{array}{l}\uparrow \text { motor activity } \\
\downarrow \text { vertical activity } \\
\downarrow \text { anxiety } \\
\uparrow \text { motor activity } \\
\downarrow \text { social interaction } \\
\uparrow \text { motor activity } \\
\uparrow \text { vocalization } \\
\uparrow \text { latencies to fall } \\
\uparrow \text { spatial learning and memory } \\
\downarrow \text { startle response } \\
\end{array}$ & $42,62,64$ \\
\hline$\downarrow$ NL4 & NL4 (-/-) & $\begin{array}{l}\text { Social interaction } \\
\text { Resident-intruder test } \\
\text { Ultrasonic vocalization } \\
\text { Nest building } \\
\text { Marble burying }\end{array}$ & $\begin{array}{l}\downarrow \text { social interaction } \\
\downarrow \text { social aggression } \\
\downarrow \text { vocalization } \\
\downarrow \text { nest building } \\
\uparrow \text { stereotyped behavior }\end{array}$ & 65,66 \\
\hline$\downarrow \mathrm{NRXN}-1 \alpha$ & NRXN-1 $\alpha(-/-)$ & $\begin{array}{l}\text { Home cage task } \\
\text { Light/dark test } \\
\text { Social approach test } \\
\text { Social investigation task } \\
\text { Social novelty preference } \\
\text { Nest Building } \\
\text { Rotarod } \\
\text { Repetitive Grooming } \\
\text { Prepulse Inhibition } \\
\text { Acoustic startle reactivity }\end{array}$ & $\begin{array}{l}\downarrow \text { motor activity } \\
\downarrow \text { motor activity } \\
\uparrow \text { anxiety } \\
\downarrow \text { motor activity } \\
\uparrow \text { degree of social approach } \\
\downarrow \text { social investigation } \\
\uparrow \text { aggression } \\
\uparrow \text { social novelty preference } \\
\downarrow \text { nest building } \\
\uparrow \text { motor learning } \\
\uparrow \text { stereotyped behavior } \\
\downarrow \text { prepulse inhibition } \\
\uparrow \text { startle response } \\
\end{array}$ & 68,69 \\
\hline
\end{tabular}




\begin{tabular}{|c|c|c|c|c|}
\hline Alteration & Model & Behavioral test & Result & Ref. \\
\hline$\downarrow$ NRXN-2 $\alpha$ & NRXN-2 $\alpha(-/-)$ & $\begin{array}{l}\text { Home cage task } \\
\text { Open field } \\
\text { Elevated plus maze } \\
\text { Light/dark test } \\
\text { Emergence test } \\
\text { Social investigation task } \\
\text { Social novelty preference } \\
\text { 3-chamber sociability } \\
\text { Nest building } \\
\text { Repetitive grooming } \\
\text { Novel object exploration }\end{array}$ & $\begin{array}{l}\downarrow \text { motor activity } \\
\downarrow \text { motor activity } \\
\uparrow \text { anxiety } \\
\uparrow \text { anxiety } \\
\downarrow \text { motor activity } \\
\uparrow \text { anxiety } \\
\uparrow \text { anxiety } \\
\downarrow \text { social investigation } \\
\downarrow \text { social memory } \\
\downarrow \text { sociability } \\
\downarrow \text { motor activity } \\
\downarrow \text { nest building } \\
\uparrow \text { stereotyped behavior } \\
\downarrow \text { novel object exploration }\end{array}$ & 71,72 \\
\hline$\downarrow$ Shank1 & Shank1 (-/-) & $\begin{array}{l}\text { Open field } \\
\text { Light/dark test } \\
\text { Ultrasonic vocalization } \\
\text { Scent marking } \\
\text { Rotarod } \\
\text { Eight-arm radial maze } \\
\text { Fear conditioning test }\end{array}$ & $\begin{array}{l}\downarrow \text { motor activity } \\
\uparrow \text { anxiety } \\
\downarrow \text { motor activity } \\
\uparrow \text { anxiety } \\
\downarrow \text { vocalization } \\
\downarrow \text { levels of scent marks } \\
\downarrow \text { motor coordination } \\
\uparrow \text { spatial learning } \\
\downarrow \text { long-term retention of information } \\
\downarrow \text { freezing response }\end{array}$ & $73-75$ \\
\hline$\downarrow$ Shank2 & Shank2 (-/-) & $\begin{array}{l}\text { Open field } \\
\text { Elevated plus maze } \\
\text { Light/dark test } \\
\text { Social interaction } \\
\text { 3-chamber sociability } \\
\text { Ultrasonic vocalization } \\
\text { Nest building } \\
\text { Repetitive grooming } \\
\text { Repetitive jumping } \\
\text { Morris water maze } \\
\text { Novel object recognition }\end{array}$ & $\begin{array}{l}\uparrow \text { motor activity } \\
\uparrow \text { anxiety } \\
\uparrow \text { anxiety } \\
\downarrow \text { social interaction } \\
\uparrow \text { latency to first contact } \\
\downarrow \text { conspecific recognition } \\
\downarrow \text { interest for social novelty } \\
\downarrow \text { vocalization } \\
\downarrow \text { nest building } \\
\uparrow \text { stereotyped behavior } \\
\uparrow \text { stereotyped behavior } \\
\downarrow \text { spatial learning and memory } \\
\uparrow \text { grooming }\end{array}$ & 76,77 \\
\hline , $\downarrow$ Shank3 & $\begin{array}{l}\text { Shank3 (-/-) } \\
\text { Shank3 (+/-) }\end{array}$ & $\begin{array}{l}\text { Ultrasonic vocalizations } \\
\text { Nest building } \\
\text { Rotarod } \\
\text { Repetitive grooming } \\
\text { Hole-board test } \\
\text { Marble burying } \\
\text { Morris water maze } \\
\text { Novel object recognition } \\
\text { Test of hotplate sensitivity Foot- } \\
\text { misplacement test } \\
\text { Tests of vertical placement } \\
\text { Delayed climbing down }\end{array}$ & $\begin{array}{l}\downarrow \text { motor activity } \\
\downarrow \text { motor activity } \\
\uparrow \text { grooming } \\
\downarrow \text { rearing activity } \\
\uparrow \text { anxiety } \\
\uparrow \text { anxiety } \\
\downarrow \text { social interaction } \\
\downarrow \text { social novelty preference } \\
\downarrow \text { social interaction } \\
\uparrow \text { grooming } \\
\uparrow \text { sifting through bedding materials } \\
\uparrow \text { latency to first interaction } \\
\downarrow / \uparrow \text { vocalization } \\
\uparrow \text { avoidance of inanimate objects } \\
\downarrow \text { motor coordination } \\
\downarrow \text { motor learning } \\
\uparrow \text { stereotyped behavior } \\
\uparrow \text { stereotyped behavior } \\
\uparrow \text { avoidance of inanimate objects } \\
\downarrow \text { spatial learning and memory } \\
\downarrow \text { preference for the novel object } \\
\uparrow \text { sensitivity to heat } \\
\uparrow \text { foot-faults } \\
\uparrow \text { motor abnormalities } \\
\uparrow \text { motor abnormalities }\end{array}$ & $78-82$ \\
\hline
\end{tabular}

$\uparrow$ (increased), $\downarrow$ (decreased), -/- (homozygote knockout), +/- (heterozygote knockout), NL (neuroligin), NRXN (neurexin) 
in the elevated plus maze or light/dark test. Impaired motor performance on the rotarod, impaired learning and memory in novel object recognition were also observed, however, acquisition of the Morris water maze test and fear conditioning were found to be normal ${ }^{78,79}$.

Mutant mice with deletion of exons 4-9 (JAX 017442) were described by Wang and colleagues (2011) (ref. ${ }^{80}$ ). These animals had impaired sociability, social novelty, social interaction in freely interacting pairs, abnormal ultrasonic vocalization, and increased self-grooming and stereotypic investigation of novel objects. Impaired motor performance on the rotarod and impaired learning and memory in the Morris water maze test as well as in novel object recognition test were also observed. However, their anxiety and locomotor activity were at normal levels.

Peça et al. ${ }^{81}$ generated mouse line targeting exons 4-7 and another targeting exon 13-16. Because of the more profound phenotypes in the latter, the authors of this study focused attention and further study on exon 13- 16 of the mutant mice. These mice displayed alterations in social behavior including impaired sociability and preference for social novelty, as well as decreased pair interaction, and profound self- grooming. They also showed increased anxiety in the elevated zero maze and light/dark test, normal activity in the open field test, and normal motor performance on the rotarod. In the Morris water maze test, mice displayed normal acquisition and flexibility in reversal learning.

Kouser et al. ${ }^{82}$ targeted exon 21 of Shank3, reporting some ASD-related behaviors. These mice exhibited impaired social novelty in the three chamber test but normal social interaction or social learning during reciprocal social interaction with a juvenile mouse. Mice also showed impaired nest building, normal adult ultrasonic vocalizations, and increased self-grooming. In the Morris water maze test, impaired learning and memory was demonstrated. Anxiety-like behavior was manifested in the light/dark test but not in the elevated plus maze test and the open field test. They also reported a decreased activity in mice when initially presented to the open field and impaired motor performance on the rotarod. Table 2 summarizes the key behavioral changes in mouse autism model with respect to alterations in cell adhesion molecules and scaffolding proteins.

\section{CONCLUSIONS}

For effective use of animals in brain research it is essential to determine the most appropriate animal model. However, for autism, its heterogeneity makes it difficult to generalize the information acquired from any single animal model or test. In this review, we aimed to show the importance of changes in synapses or synaptogenesis which may be involved in the pathogenesis of ASD. We describes animal genetic models of ASD with respect to alterations in cell adhesion molecules and scaffolding proteins. We also showed synapse-specific or model-specific defects associated with a given genotype in these models. Characterization of mouse models carrying genetic variations could help us study the mechanisms of autism development in humans more efficiently. However, it will be necessary to apply new analytic paradigms in using genetically modified mice for understanding autism etiology in humans. Further studies are needed to create animal models with mutations that match the molecular and neural bases of autism.

Acknowledgement: The work was supported by the project 2/0119/15 of the Grant Agency of the Ministry of Education, Science and Research and the Slovak Academy of Sciences (VEGA), and by the projects APVV0253-10 and APVV-0254-11 of the Slovak Research and Development Agency.

Author contributions: MZ: literature search, manuscript writing; JB: concept, manuscript writing; JH: tables, text corrections; DO: proofreading, text corrections.

Conflict of interest statement: The authors state there are no conflicts of interest regarding the publication of this article.

\section{REFERENCES}

1. Singh K, Connors SL, Macklin EA, Smith KD, Fahey JW, Talalay P, Zimmerman AW. Sulforaphane treatment of autism spectrum disorder (ASD). Proc Natl Acad Sci U S A 2014;111(43):15550-5.

2. WHO report EB133/4 on Comprehensive and coordinated efforts for the management of autism spectrum disorders, 8 April 2013

3. Xuan IC, Hampson DR. Gender-dependent effects of maternal immune activation on the behavior of mouse offspring. PLoS One 2014;9(8):e104433.

4. Hamilton SM, Green JR, Veeraragavan S, Yuva L, McCoy A, Wu Y, Warren J, Little L, Ji D, Cui X, Weinstein E, Paylor R. Fmr1 and Nlgn3 knockout rats: novel tools for investigating autism spectrum disorders. Behav Neurosci 2014;128(2):103-9.

5. Cohen OS, Varlinskaya El, Wilson CA, Glatt SJ, Mooney SM. Acute prenatal exposure to a moderate dose of valproic acid increases social behavior and alters gene expression in rats. Int J Dev Neurosci 2013;31(8):740-50.

6. Oddi D, Subashi E, Middei S, Bellocchio L, Lemaire-Mayo V, Guzmán M, Crusio WE, D'Amato FR, Pietropaolo S. Early social enrichment rescues adult behavioral and brain abnormalities in a mouse model of fragile X syndrome. Neuropsychopharmacology 2015;40(5):111322.

7. Courchesne E, Pierce K. Why the frontal cortex in autism might be talking only to itself: local over-connectivity but long-distance disconnection. Curr Opin Neurobiol 2005;15(2):225-30.

8. Williams EL, Casanova MF. Above genetics: lessons from cerebral development in autism. Transl Neurosci 2011;2(2):106-20.

9. Clowry G, Molnár Z, Rakic P. Renewed focus on the developing human neocortex. J Anat 2010;217(4):276-88.

10. Wang SS, Kloth AD, Badura A. The cerebellum, sensitive periods, and autism. Neuron 2014;83(3):518-32.

11. Jüttner R, Rathjen FG. Molecular analysis of axonal target specificity and synapse formation. Cell Mol Life Sci 2005;62(23):2811-27.

12. Salie R, Niederkofler $V$, Arber S. Patterning molecules: multitasking in the nervous system. Neuron 2005;45(2):189-92.

13. Waites CL, Craig AM, Garner CC. Mechanisms of vertebrate synaptogenesis. Annu Rev Neurosci 2005;28:251-74.

14 Yamagata M, Sanes JR, Weiner JA. Synaptic adhesion molecules. Curr Opin Cell Biol 2003;15(5):621-32.

15. Melom JE, Littleton JT. Synapse development in health and disease. Curr Opin Genet Dev 2011;21(3):256-61.

16. Ataman B, Ashley J, Gorczyca M, Ramachandran P, Fouquet W, Sigrist SJ, Budnik V. Rapid activity-dependent modifications in synaptic structure and function require bidirectional Wnt signaling. Neuron 2008;57(5):705-18. 
17. Ciani L, Krylova O, Smalley MJ, Dale TC, Salinas PC. A divergent canonical WNT-signaling pathway regulates microtubule dynamics: dishevelled signals locally to stabilize microtubules. J Cell Bio 2004;164(2):243-53.

18. Speese SD, Budnik V. Wnts: up-and-coming at the synapse. Trends Neurosci 2007;30(6):268-75

19. Mosca TJ, Schwarz TL. The nuclear import of Frizzled2-C by Importins- $\beta 11$ and $\alpha 2$ promotes postsynaptic development. Nat Neurosci 2010;13(8):935-43.

20. Ball RW, Warren-Paquin M, Tsurudome $K$, Liao EH, Elazzouzi $F$ Cavanagh C, An BS, Wang TT, White JH, Haghighi AP. Retrograde BMP signaling controls synaptic growth at the NMJ by regulating trio expression in motor neurons. Neuron 2010;66(4):536-49.

21. Corbetta S, Gualdoni S, Ciceri G, Monari M, Zuccaro E, Tybulewicz VL, de Curtis I. Essential role of Rac1 and Rac3 GTPases in neurona development. FASEB J 2009;23(5):1347-57.

22. Chen LY, Rex CS, Babayan AH, Kramar EA, Lynch G, Gall CM Lauterborn JC. Physiological activation of synaptic Rac > PAK ( $p-21$ activated kinase) signaling is defective in a mouse model of fragile X syndrome. J Neurosci 2010; 30(33):10977-84.

23. Südhof TC. Neuroligins and neurexins link synaptic function to cognitive disease. Nature 2008;455(7215):903-11.

24. Reissner C, Runkel F, Missler M. Neurexins. Genome Biol 2013;14(9):213.

25. McGee A, Li G, Lu Z, Qiu S. Convergent synaptic and circuit substrates underlying autism genetic risks. Front Biol (Beijing) 2014;9(2):137-50

26. Chen J, Yu S, Fu Y, Li X. Synaptic proteins and receptors defects in autism spectrum disorders. Front Cell Neurosci 2014;8:276.

27. Song JY, Ichtchenko K, Südhof TC, Brose N. Neuroligin 1 is a postsynaptic cell-adhesion molecule of excitatory synapses. Proc Natl Acad Sci U S A 1999;96(3):1100-5.

28. Bolliger MF, Pei J, Maxeiner S, Boucard AA, Grishin N V, Südhof TC. Unusually rapid evolution of Neuroligin-4 in mice. Proc Natl Acad Sci U S A 2008;105(17):6421-6.

29. Varoqueaux F, Aramuni G, Rawson RL, Mohrmann R, Missler M Gottmann K, Zhang W, Südhof TC, Brose N. Neuroligins determine synapse maturation and function. Neuron 2006;51(6):741-54

30. Gilbert M, Smith J, Roskams A-J, Auld VJ. Neuroligin 3 is a vertebrate gliotactin expressed in the olfactory ensheathing glia, a growthpromoting class of macroglia. Glia 2001;34(3):151-64.

31. Sheng M, Kim E. The Shank family of scaffold proteins. J Cell Sci 2000;113(Pt 11):1851-6.

32. Bourgeron T. A synaptic trek to autism. Curr Opin Neurobio 2009;19(2):231-4.

33. Hutsler JJ, Zhang $\mathrm{H}$. Increased dendritic spine densities on cortical projection neurons in autism spectrum disorders. Brain Res 2010;1309:83-94

34. Glantz LA, Lewis DA. Decreased dendritic spine density on prefronta cortical pyramidal neurons in schizophrenia. Arch Gen Psychiatry 2000;57(1):65-73.

35. Tackenberg C, Ghori A, Brandt R. Thin, stubby or mushroom: spine pathology in Alzheimer's disease. Curr Alzheimer Res 2009;6(3):2618.

36. Zoghbi HY. Postnatal neurodevelopmental disorders: meeting at the synapse? Science 2003;302(5646):826-30.

37. Penzes $P$, Cahill ME, Jones KA, VanLeeuwen J-E, Woolfrey KM Dendritic spine pathology in neuropsychiatric disorders. Nat Neurosci 2011;14(3):285-93.

38. Pardo CA, Eberhart CG. The neurobiology of autism. Brain Patho 2007;17(4):434-47.

39. Spooren W, Lindemann L, Ghosh A, Santarelli L. Synapse dysfunction in autism: a molecular medicine approach to drug discovery in neurodevelopmental disorders. Trends Pharmacol Sci 2012;33(12):669 84

40. Rubenstein JLR, Merzenich MM. Model of autism: increased ratio of excitation/inhibition in key neural systems. Genes Brain Behav 2003;2(5):255-67.

41. Jamain $S$, Quach $H$, Betancur $C$, Råstam $M$, Colineaux C, Gillberg IC, Soderstrom H, Giros B, Leboyer M, Gillberg C, Bourgeron T; Paris Autism Research International Sibpair Study. Mutations of the $X$-linked genes encoding neuroligins NLGN3 and NLGN4 are associated with autism. Nat Genet 2003;34(1):27-9.

42. Tabuchi K, Blundell J, Etherton MR, Hammer RE, Powell CM, Südhof TC. A neuroligin-3 mutation implicated in autism increases inhibitory synaptic transmission in mice. Science 2007;318(5847):71-6.
43. Laumonnier F, Bonnet-Brilhault F, Gomot M, Blanc R, David A, Moizard MP, Raynaud M, Ronce N, Lemonnier E, Calvas P, Laudier B, Chelly J, Fryns JP, Ropers HH, Hamel BC, Andres C, Barthélémy $C$, Moraine $\mathrm{C}$, Briault S. X-linked mental retardation and autism are associated with a mutation in the NLGN4 gene, a member of the neuroligin family. Am J Hum Genet 2004;74(3):552-7.

44. Friedman A, Luiselli JK. Excessive daytime sleep: behavioral assessment and intervention in a child with autism. Behav Modif 2008;32(4):548-55.

45. Autism Genome Project Consortium, Szatmari P, Paterson AD Zwaigenbaum L, Roberts W, Brian J, Liu XQ, Vincent JB, Skaug JL, Thompson AP, Senman L, Feuk L, Qian C, Bryson SE, Jones MB, Marshall CR, Scherer SW, Vieland VJ, Bartlett C, Mangin LV, Goedken $\mathrm{R}$, Segre A, Pericak-Vance MA, Cuccaro ML, Gilbert JR, Wright $\mathrm{HH}$ Abramson RK, Betancur C, Bourgeron T, Gillberg C, Leboyer M Buxbaum JD, Davis KL, Hollander E, Silverman JM, Hallmayer J, Lotspeich L, Sutcliffe JS, Haines JL, Folstein SE, Piven J, Wassink TH, Sheffield V, Geschwind DH, Bucan M, Brown WT, Cantor RM, Constantino JN, Gilliam TC, Herbert M, Lajonchere C, Ledbetter DH, Lese-Martin C, Miller J, Nelson S, Samango-Sprouse CA, Spence S, State $\mathrm{M}$, Tanzi RE, Coon H, Dawson G, Devlin B, Estes A, Flodman P, Klei L, McMahon WM, Minshew N, Munson J, Korvatska E, Rodier PM, Schellenberg GD, Smith M, Spence MA, Stodgell C, Tepper PG, Wijsman EM, Yu CE, Rogé B, Mantoulan C, Wittemeyer K, Poustka A, Felder B, Klauck SM, Schuster C, Poustka F, Bölte S, Feineis-Matthews S, Herbrecht E, Schmötzer G, Tsiantis J, Papanikolaou K, Maestrini E, Bacchelli E, Blasi F, Carone S, Toma C, Van Engeland H, de Jonge M, Kemner C, Koop F, Langemeijer M, Hijmans C, Staal WG, Baird G, Bolton PF, Rutter ML, Weisblatt E, Green J, Aldred C, Wilkinson JA, Pickles A, Le Couteur A, Berney T, McConachie H, Bailey AJ, Francis K, Honeyman G, Hutchinson A, Parr JR, Wallace S, Monaco AP, Barnby G, Kobayashi K, Lamb JA, Sousa I, Sykes N, Cook EH, Guter SJ, Leventhal BL, Salt J, Lord C, Corsello C, Hus V, Weeks DE, Volkmar F, Tauber M, Fombonne E, Shih A, Meyer KJ. Mapping autism risk loci using genetic linkage and chromosomal rearrangements. Nat Genet 2007;39(3):319-28.

46. Vaags AK, Lionel AC, Sato D, Goodenberger M, Stein QP, Curran S, Ogilvie C, Ahn JW, Drmic I, Senman L, Chrysler C, Thompson A Russell C, Prasad A, Walker S, Pinto D, Marshall CR, Stavropoulos DJ, Zwaigenbaum L, Fernandez BA, Fombonne E, Bolton PF, Collier DA, Hodge JC, Roberts W, Szatmari P, Scherer SW. Rare deletions at the neurexin 3 locus in autism spectrum disorder. Am J Hum Genet 2012;90(1):133-41.

47. Bakkaloglu B, O'Roak BJ, Louvi A, Gupta AR, Abelson JF, Morgan TM, Chawarska K, Klin A, Ercan-Sencicek AG, Stillman AA, Tanriover G, Abrahams BS, Duvall JA, Robbins EM, Geschwind DH, Biederer T, Gunel M, Lifton RP, State MW. Molecular cytogenetic analysis and resequencing of contactin associated protein-like 2 in autism spectrum disorders. Am J Hum Genet 2008;82(1):165-73.

48. Alarcón M, Abrahams BS, Stone JL, Duvall JA, Perederiy JV, Bomar JM, Sebat J, Wigler M, Martin CL, Ledbetter DH, Nelson SF, Cantor RM Geschwind DH. Linkage, association, and gene-expression analyses identify CNTNAP2 as an autism-susceptibility gene. Am J Hum Genet 2008;82(1):150-9.

49. Arking DE, Cutler DJ, Brune CW, Teslovich TM, West K, Ikeda M, Rea A, Guy M, Lin S, Cook EH, Chakravarti A. A common genetic variant in the neurexin superfamily member CNTNAP2 increases familial risk of autism. Am J Hum Genet 2008;82(1):160-4.

50. Sampath S, Bhat S, Gupta S, O'Connor A, West AB, Arking DE, Chakravarti A. Defining the contribution of CNTNAP2 to autism susceptibility. PLoS One 2013;8(10):e77906.

51. Durand CM, Betancur C, Boeckers TM, Bockmann J, Chaste $P$ Fauchereau F, Nygren G, Rastam M, Gillberg IC, Anckarsäter H, Sponheim E, Goubran-Botros H, Delorme R, Chabane N, MourenSimeoni MC, de Mas P, Bieth E, Rogé B, Héron D, Burglen L, Gillberg $C$, Leboyer $M$, Bourgeron T. Mutations in the gene encoding the synaptic scaffolding protein SHANK3 are associated with autism spectrum disorders. Nat Genet 2007;39(1):25-7

52. Berkel $S$, Marshall CR, Weiss $B$, Howe J, Roeth $R$, Moog U, Endris V, Roberts W, Szatmari P, Pinto D, Bonin M, Riess A, Engels H, Sprengel $\mathrm{R}$, Scherer SW, Rappold GA. Mutations in the SHANK2 synaptic scaffolding gene in autism spectrum disorder and mental retardation. Nat Genet 2010;42(6):489-91.

53. Pinto D, Pagnamenta AT, Klei L, Anney R, Merico D, Regan R, Conroy J, Magalhaes TR, Correia C, Abrahams BS, Almeida J, Bacchelli E, Bader 
GD, Bailey AJ, Baird G, Battaglia A, Berney T, Bolshakova N, Bölte S, Bolton PF, Bourgeron T, Brennan S, Brian J, Bryson SE, Carson AR, Casallo G, Casey J, Chung BH, Cochrane L, Corsello C, Crawford EL, Crossett A, Cytrynbaum C, Dawson G, de Jonge M, Delorme R, Drmic I, Duketis E, Duque F, Estes A, Farrar P, Fernandez BA, Folstein SE, Fombonne E, Freitag CM, Gilbert J, Gillberg C, Glessner JT, Goldberg J, Green A, Green J, Guter SJ, Hakonarson H, Heron EA, Hill M, Holt R, Howe JL, Hughes G, Hus V, Igliozzi R, Kim C, Klauck SM, Kolevzon A, Korvatska O, Kustanovich V, Lajonchere CM, Lamb JA, Laskawiec M, Leboyer M, Le Couteur A, Leventhal BL, Lionel AC, Liu XQ, Lord C, Lotspeich L, Lund SC, Maestrini E, Mahoney W, Mantoulan C, Marshall CR, McConachie $\mathrm{H}$, McDougle CJ, McGrath J, McMahon WM, Merikangas A, Migita O, Minshew NJ, Mirza GK, Munson J, Nelson SF, Noakes C, Noor A, Nygren G, Oliveira G, Papanikolaou K, Parr JR, Parrini B, Paton T, Pickles A, Pilorge M, Piven J, Ponting CP, Posey DJ, Poustka A, Poustka F, Prasad A, Ragoussis J, Renshaw K, Rickaby J, Roberts W, Roeder K, Roge B, Rutter ML, Bierut LJ, Rice JP, Salt J, Sansom K, Sato D, Segurado R, Sequeira AF, Senman L, Shah N, Sheffield VC, Soorya L, Sousa I, Stein O, Sykes N, Stoppion V, Strawbridge C, Tancredi R, Tansey K, Thiruvahindrapduram B, Thompson AP, Thomson S, Tryfon A, Tsiantis J, Van Engeland $\mathrm{H}$, Vincent JB, Volkmar F, Wallace S, Wang K, Wang Z, Wassink TH Webber C, Weksberg R, Wing K, Wittemeyer K, Wood S, Wu J, Yaspan BL, Zurawiecki D, Zwaigenbaum L, Buxbaum JD, Cantor RM, Cook EH, Coon H, Cuccaro ML, Devlin B, Ennis S, Gallagher L, Geschwind DH, Gill M, Haines JL, Hallmayer J, Miller J, Monaco AP, Nurnberger JI Jr, Paterson AD, Pericak-Vance MA, Schellenberg GD, Szatmari P, Vicente AM, Vieland VJ, Wijsman EM, Scherer SW, Sutcliffe JS, Betancur C. Functional impact of global rare copy number variation in autism spectrum disorders. Nature 2010;466(7304):368-72.

54. Leblond CS, Heinrich J, Delorme R, Proepper C, Betancur C, Huguet G, Konyukh M, Chaste P, Ey E, Rastam M, Anckarsäter H, Nygren G, Gillberg IC, Melke J, Toro R, Regnault B, Fauchereau F, Mercati O, Lemière $N$, Skuse $D$, Poot $M$, Holt R, Monaco AP, Järvelä I, Kantojärvi K, Vanhala R, Curran S, Collier DA, Bolton P, Chiocchetti A, Klauck SM, Poustka F, Freitag CM, Waltes R, Kopp M, Duketis E, Bacchelli E, Minopoli F, Ruta L, Battaglia A, Mazzone L, Maestrini E, Sequeira $A F$, Oliveira B, Vicente A, Oliveira G, Pinto D, Scherer SW, Zelenika D, Delepine M, Lathrop M, Bonneau D, Guinchat V, Devillard F, Assouline B, Mouren MC, Leboyer M, Gillberg C, Boeckers TM, Bourgeron T. Genetic and functional analyses of SHANK2 mutations suggest a multiple hit model of autism spectrum disorders. PLoS Genet 2012;8(2):e1002521.

55. Sato D, Lionel AC, Leblond CS, Prasad A, Pinto D, Walker S, O'Connor I, Russell C, Drmic IE, Hamdan FF, Michaud JL, Endris V, Roeth R, Delorme R, Huguet G, Leboyer M, Rastam M, Gillberg C, Lathrop $M$, Stavropoulos DJ, Anagnostou E, Weksberg R, Fombonne E, Zwaigenbaum L, Fernandez BA, Roberts W, Rappold GA, Marshal CR, Bourgeron T, Szatmari P, Scherer SW. SHANK1 deletions in males with autism spectrum disorder. Am J Hum Genet 2012;90(5):879-87.

56. Bey AL, Jiang Y-H. Overview of mouse models of autism spectrum disorders. Curr Protoc Pharmacol 2014;66:5.66.1-5.66.26.

57. Blundell J, Blaiss CA, Etherton MR, Espinosa F, Tabuchi K, Walz C, Bolliger MF, Südhof TC, Powell CM. Neuroligin 1 deletion results in impaired spatial memory and increased repetitive behavior. J Neurosci 2010;30(6):2115-29.

58. Blundell J, Tabuchi K, Bolliger MF, Blaiss CA, Brose N, Liu X, Südhof TC, Powell CM. Increased anxiety-like behavior in mice lacking the inhibitory synapse cell adhesion molecule neuroligin 2. Genes, brain Behav 2009;8(1):114-26.

59. Wöhr M, Silverman JL, Scattoni ML, Turner SM, Harris MJ, Saxena R, Crawley JN. Developmental delays and reduced pup ultrasonic vocalizations but normal sociability in mice lacking the postsynaptic cell adhesion protein neuroligin2. Behav Brain Res 2013;251:50-64

60. Radyushkin K, Hammerschmidt K, Boretius S, Varoqueaux F, El-Kordi A, Ronnenberg A, Winter D, Frahm J, Fischer J, Brose N, Ehrenreich H. Neuroligin-3-deficient mice: model of a monogenic heritable form of autism with an olfactory deficit. Genes, Brain Behav 2009;8(4):41625.

61. Shen C, Huo LR, Zhao XL, Wang PR, Zhong N. Novel interactive partners of neuroligin 3: new aspects for pathogenesis of autism. J Mol Neurosci 2015;56(1):89-101.

62. Chadman KK, Gong S, Scattoni ML, Boltuck SE, Gandhy SU, Heintz N, Crawley JN. Minimal aberrant behavioral phenotypes of neuroligin-3 R451C knockin mice. Autism Res 2008;1 (3):147-58.
63. Comoletti D, De Jaco A, Jennings LL, Flynn RE, Gaietta G, Tsigelny I, Ellisman MH, Taylor P. The Arg451Cys-neuroligin-3 mutation associated with autism reveals a defect in protein processing. J Neurosci 2004;24(20):4889-93.

64. Jaramillo TC, Liu S, Pettersen A, Birnbaum SG, Powell CM. Autismrelated neuroligin-3 mutation alters social behavior and spatial learning. Autism Res 2014;7(2):264-72.

65. Jamain S, Radyushkin K, Hammerschmidt K, Granon S, Boretius S, Varoqueaux F, Ramanantsoa N, Gallego J, Ronnenberg A, Winter D, Frahm J, Fischer J, Bourgeron T, Ehrenreich H, Brose N. Reduced social interaction and ultrasonic communication in a mouse model of monogenic heritable autism. Proc Natl Acad Sci U S A 2008;105(5):1710-15.

66. El-Kordi A, Winkler D, Hammerschmidt K, Kästner A, Krueger $D$, Ronnenberg A, Ritter C, Jatho J, Radyushkin K, Bourgeron T, Fischer $\mathrm{J}$, Brose N, Ehrenreich H. Development of an autism severity score for mice using Nlgn4 null mutants as a construct-valid model of heritable monogenic autism. Behav Brain Res 2013;251:41-9.

67. Ey E, Yang M, Katz AM, Woldeyohannes L, Silverman JL, Leblond CS, Faure P, Torquet N, Le Sourd AM, Bourgeron T, Crawley JN. Absence of deficits in social behaviors and ultrasonic vocalizations in later generations of mice lacking neuroligin4. Genes Brain Behav 2012;11:928-41.

68. Etherton MR, Blaiss CA, Powell CM, Südhof TC. Mouse neurexin-1alpha deletion causes correlated electrophysiological and behavioral changes consistent with cognitive impairments. Proc Natl Acad Sci U S A 2009;106(42):17998-8003.

69. Grayton HM, Missler M, Collier DA, Fernandes C. Altered social behaviours in neurexin 1a knockout mice resemble core symptoms in neurodevelopmental disorders. PLoS One 2013;8(6):e67114.

70. Tabuchi K, Südhof TC. Structure and evolution of neurexin genes: insight into the mechanism of alternative splicing. Genomics 2002;79(6):849-59.

71. Born G, Grayton HM, Langhorst H, Dudanova I, Rohlmann A Woodward BW, Collier DA, Fernandes C, Missler M. Genetic targeting of NRXN2 in mice unveils role in excitatory cortical synapse function and social behaviors. Front Synaptic Neurosci 2015;7(3):3.

72. Dachtler J, Glasper J, Cohen RN, Ivorra JL, Swiffen DJ, Jackson AJ, Harte MK, Rodgers RJ, Clapcote SJ. Deletion of a-neurexin II results in autism-related behaviors in mice. Transl Psychiatry 2014;4(11):e484.

73. Hung AY, Futai K, Sala C, Valtschanoff JG, Ryu J, Woodworth MA, Kidd FL, Sung CC, Miyakawa T, Bear MF, Weinberg RJ, Sheng M. Smaller dendritic spines, weaker synaptic transmission, but enhanced spatial learning in mice lacking Shank1. J Neurosci 2008;28(7):1697-708.

74. Silverman JL, Turner SM, Barkan CL, Tolu SS, Saxena R, Hung AY, Sheng M, Crawley JN. Sociability and motor functions in Shank1 mutant mice. Brain Res 2011;1380:120-37.

75. Wöhr M, Roullet Fl, Hung AY, Sheng M, Crawley JN. Communication impairments in mice lacking Shank1: reduced levels of ultrasonic vocalizations and scent marking behavior. PLoS One 2011;6(6):e20631 .

76. Won H, Lee H-R, Gee HY, Mah W, Kim Jl, Lee J, Ha S, Chung C, Jung ES, Cho YS, Park SG, Lee JS, Lee K, Kim D, Bae YC, Kaang BK, Lee MG, Kim E. Autistic-like social behaviour in Shank2-mutant mice improved by restoring NMDA receptor function. Nature 2012;486(7402):261-5.

77. Schmeisser MJ, Ey E, Wegener S, Bockmann J, Stempel AV, Kuebler A, Janssen AL, Udvardi PT, Shiban E, Spilker C, Balschun D, Skryabin BV, Dieck St, Smalla KH, Montag D, Leblond CS, Faure P, Torquet N, Le Sourd AM, Toro R, Grabrucker AM, Shoichet SA, Schmitz D, Kreutz MR, Bourgeron T, Gundelfinger ED, Boeckers TM. Autistic-like behaviours and hyperactivity in mice lacking ProSAP1/Shank2. Nature 2012;486(7402):256-60

78. Bozdagi O, Sakurai T, Papapetrou D, Wang X, Dickstein DL, Takahashi N, Kajiwara Y, Yang M, Katz AM, Scattoni ML, Harris MJ, Saxena R, Silverman JL, Crawley JN, Zhou Q, Hof PR, Buxbaum JD. Haploinsufficiency of the autism-associated Shank3 gene leads to deficits in synaptic function, social interaction, and social communication. Mol Autism 2010;1(1):1-15.

79. Yang M, Bozdagi O, Scattoni ML, Wöhr M, Roullet Fl, Katz AM, Abrams DN, Kalikhman D, Simon H, Woldeyohannes L, Zhang JY, Harris MJ, Saxena R, Silverman JL, Buxbaum JD, Crawley JN. Reduced excitatory neurotransmission and mild autism-relevant phenotypes in adolescent Shank3 null mutant mice. J Neurosci 2012;32(19):6525-41.

80. Wang X, McCoy PA, Rodriguiz RM, Pan Y, Je HS, Roberts AC, Kim CJ, Berrios J, Colvin JS, Bousquet-Moore D, Lorenzo I, Wu G, Weinberg RJ, Ehlers MD, Philpot BD, Beaudet AL, Wetsel WC, Jiang YH. Synaptic 
dysfunction and abnormal behaviors in mice lacking major isoforms of Shank3. Hum Mol Genet 2011;20(15):3093-108.

81. Peça J, Feliciano C, Ting JT, Wang W, Wells MF, Venkatraman TN, Lascola CD, Fu Z, Feng G. Shank3 mutant mice display autistic-like behaviours and striatal dysfunction. Nature 2011;472(7344):437-42.
82. Kouser M, Speed HE, Dewey CM, Reimers JM, Widman AJ, Gupta N, Liu S, Jaramillo TC, Bangash M, Xiao B, Worley PF, Powell CM. Loss of predominant Shank3 isoforms results in hippocampus-dependent impairments in behavior and synaptic transmission. J Neurosci 2013;33(47):18448-68. 